\title{
9
}

\section{WRITING THE NATION IN TWO LANGUAGES: THE DICTIONARY OF WELSH BIOGRAPHY}

\author{
DAFYDD JOHNSTON
}

Wales was the first of the four nations of the British Isles to establish its own separate national biographical dictionary, distinct from and yet necessarily modelled on the Dictionary of National Biography. The Welsh project was publicly announced in 1938, and the first volume, Y Bywgraffiadur Cymreig hyd 1940, was published in the Welsh language in 1953, followed by its English counterpart, The Dictionary of Welsh Biography Down to 1940, in 1959. ${ }^{1}$ This chapter on the relationship between the two languages in the project, from the print volumes through to the current website, ${ }^{2}$ will argue that bilingual publication has been vital both as a representation of the lived experience of the Welsh people, and as an assertion of distinctive national identity. First, however, a brief historical survey will highlight the multilingual nature of life writing in Wales from the earliest times, and its deployment at key points in the relationship between Wales and England.

1 John Edward Lloyd and R. T. Jenkins, eds, Y Bywgraffiadur Cymreig hyd 1940 (Llundain: Anrhydeddus Gymdeithas y Cymmrodorion, 1953); John Edward Lloyd and R. T. Jenkins, eds, The Dictionary of Welsh Biography Down to 1940 (London: The Honourable Society of Cymmrodorion, 1959).

2 Dictionary of Welsh Biography/Y Bywgraffiadur Cymreig, National Library of Wales and the Honourable Society of Cymmrodorion of London, biography.wales/ and bywgraffiadur.cymru/ [henceforth $D W B$ ]. 


\section{The History of Life Writing in Wales}

The very earliest biographical work by a Welsh person, Asser's Latin life of King Alfred of Wessex up to the year 895, belongs to a period before either Wales or England existed as political entities, but it does record a crucial point in the formation of the English nation, if not the Welsh. Asser was a member of the clerical community of St David's in south-west Wales who had been invited to raise standards of learning at Alfred's court. ${ }^{3}$ Asser's political allegiance cut across ethnic divisions, one of his main aims in his dealings with Alfred being to enlist his support for St David's against an oppressive local ruler. His biography promoted the Carolingian ideal of the learned Christian king, as expressed in the lives of Charlemagne and his son Louis the Pious, and its hermeneutic Latinity was an integral part of the work's message proclaiming loyalty to an international scholarly community. What is particularly interesting about this work when considered in the context of the history of biographical writing in and from Wales is that it reverses what later became the dominant flow of cultural influence, since St David's was evidently a centre of learning capable of providing the scholarship and literary skills necessary for the meaningful shaping of an English life. When Asser in his turn became the subject of biography in the Enlightenment period, his case was used to support belief in the antiquity of Welsh learning.

A key driver in the development of a Welsh national consciousness was the external threat posed by the Norman invasions from the late eleventh century onwards, and it is surely no coincidence that the first biographies - both religious and secular - to be composed in Wales relate to resistance to the Normans. The earliest life of a secular ruler is that of Gruffudd ap Cynan (c. 1055-1137), composed in Latin probably before 1148 and translated into Welsh by 1170 , which is the earliest Welshlanguage biography. ${ }^{4}$ Gruffudd was king of Gwynedd in north-west Wales, and is primarily remembered for establishing his kingdom as a bastion

3 See Patrick Wormald, 'Asser (d. 909)', Oxford Dictionary of National Biography, Oxford University Press, 2004; online edn, September 2004, accessed 29 June 2017, www.oxforddnb.com/ view/article/810. doi.org/10.1093/ref:odnb/810; D. P. Kirby, 'Asser and His Life of King Alfred', Studia Celtica 6 (1971): 12-35.

4 The Latin original was long thought to be lost, but was recently discovered and edited by Paul Russell, Vita Griffini Filii Conani (Cardiff: University of Wales Press, 2005). For the Welsh text, see D. Simon Evans, ed., Historia Gruffud vab Kenan (Cardiff: University of Wales Press, 1977); and D. Simon Evans, trans., A Medieval Prince of Wales: The Life of Gruffudd ap Cynan (Felinfach: Llanerch Enterprises, 1990). 
of Welsh independence which stood firm against the Normans under his descendants until the late thirteenth century, and which continues to be a source of inspiration to Welsh nationalists to this day. However, Gruffudd's ethnic background was more complex than this teleological view might suggest. Born and brought up in Ireland, the son of a Welsh father and an Irish Viking mother, he could justifiably have been included in the Dictionary of Irish Biography, and his early military exploits were against Welsh rivals as much as against the Normans.

It has been argued that the Latin life was composed not in Gwynedd, as one might expect, but at St David's in the south-west, with the aim of bolstering the aspirations of that diocese-which were supported by Gruffudd's son Owain Gwynedd-as a metropolitan see. One feature suggestive of a St David's provenance is the use of the term Cambria for Wales (derived from Camber, son of Brutus, ancestor of the Welsh people according to Geoffrey of Monmouth's Historia Regum Britanniae), a neologism which is indicative of a new national consciousness, later taken up by Cambro-Latin writers of the Renaissance. ${ }^{5}$ The Welsh translation appears to have been written in Gwynedd, and this is an early example of translation being associated with a change in perspective.

Opposition to Norman ecclesiastical reforms motivated the earliest hagiography in Wales, promoting the claims of the dioceses of Llandaff and St David's against encroachment by Canterbury. Two twelfth-century manuscripts contain collections of Latin lives celebrating local saints, the most significant of which is the life of St David, composed about 1094 by Rhigyfarch of Llanbadarn Fawr, another notable centre of ecclesiastical learning. ${ }^{6}$ This was translated into Welsh in the fourteenth century as the spread of David's cult established him as patron saint of Wales. Numerous other translations of the lives of local and international saints made hagiography the most prominent form of biographical writing in Welsh in the premodern period. ${ }^{7}$

The earliest biography of a Welsh person in English is the Life of Sir Rhys ap Thomas, composed in the early seventeenth century by Henry Rice, a direct descendant of the subject, and thus belonging to the genre of family

5 See Huw Pryce, 'British or Welsh? National Identity in Twelfth-Century Wales', English Historical Review 116, no. 468 (2001): 775-801 (at 797-98). doi.org/10.1093/ehr/CXVI.468.775.

6 J. W. Evans and J. M. Wooding, eds, St David of Wales: Cult, Church and Nation (Woodbridge: Boydell and Brewer, 2007).

7 For texts and translations, see 'Seintiau', www.welshsaints.ac.uk/. 
history. ${ }^{8}$ Again we find biography linked to a key turning point in Welsh history, the purpose of the work being to celebrate the role played by Sir Rhys in Henry Tudor's victory at Bosworth in 1485 (Rhys is claimed to have slain Richard III himself), and in the establishment of the Tudor state which led in due course to the Acts of Union between England and Wales.

The gap in Wales's political history between the age of the independent princes and the Tudor union was eventually bridged by an account of the life of Owain Glyndwr (c. 1359-c. 1415) in Thomas Pennant's A Tour in Wales (1778). ${ }^{9}$ Glyndwr was a descendant of the princes who led a rebellion against the English crown in 1400, and although ultimately unsuccessful he has been a potent figure in Welsh folklore and nationalist mythology ever since. Pennant drew on a wide range of sources, including Crown records, and his account can be seen as the first attempt at a scholarly and objective biography in the Welsh context. In so doing he created a fully shaped life worthy of a national hero to counter the English chroniclers' portrayal of a rabble-rouser whose career began and ended in obscurity. Short biographical sketches had already been a feature of Pennant's travel writing from his Scottish tours, depicting lives as an aspect of the history of place, but this lengthy excursion covering 69 pages stretched the genre to its limits. ${ }^{10}$

The development of Welsh biographical writing in the eighteenth century was a product of an antiquarian revival which sought to repossess or recreate Wales's past. It was in this period that London began to play a leading role in Welsh culture, and publications were aimed as much at a metropolitan readership as at the inhabitants of Wales. In the absence of civic institutions in Wales itself, London Welsh societies such as the Honourable Society of Cymmrodorion (literally 'earliest inhabitants') made a crucial contribution to the formation of a national consciousness. The first biographies to be published were in the Cambrian Register, a London-

8 Ralph A. Griffiths, Sir Rhys ap Thomas and His Family: A Study in the Wars of the Roses and Early Tudor Politics (Cardiff: University of Wales Press, 2014). The Life was first published in 1796 in the Cambrian Register, and as the original manuscript is lost that text is now the primary source.

9 Thomas Pennant, A Tour in Wales, MDCCLXXIII (London: Henry Hughes, 1778; 2nd edition, London: Benjamin White, 1784). For discussion, see D. Johnston, 'Shaping a Heroic Life: Thomas Pennant on Owen Glyndwr', in Enlightenment Travel and British Identities: Thomas Pennant's Tours in Scotland and Wales, eds Mary-Ann Constantine and Nigel Leask (London and New York: Anthem Press, 2017), 105-21.

10 In the three-volume edition of the Tour published in 1810 the section on Glyndwr is relegated to an appendix. 
based journal devoted to Welsh antiquities and edited by William Owen under the auspices of the Gwyneddigion society. The first two issues, published in 1796 and 1799, contained a section entitled 'Biography', which was clearly intended to show English readers that Welsh lives were worthy of interest. ${ }^{11}$ Owen was the first to produce a volume of collective biography with his Cambrian Biography of 1803, although in fact this is more of an encyclopedic index to Welsh history, literature, and legend, including numerous characters exemplifying romantic origin myths. ${ }^{12}$

The first collection of Welsh biographies to aim at historical objectivity was The Cambrian Plutarch (1824) by John H. Parry, another member of the Gwyneddigion Society. As the title implies, these are discursive essays emphasising the moral value of lives fit to be emulated (although sadly the author himself was killed in a brawl at the Prince of Wales tavern in Pentonville the following year). The 22 lives (all men) present an image of the Welsh as a people of warriors, statesmen, divines, poets, and men of letters-in short, a civilised nation worthy of its place in the British Empire. In what was to become a topos of Welsh biographical writing, the four nations of the British Isles are invoked both to claim historical priority for the Welsh and to lament their contemporary neglect:

It is a fact not to be questioned, that a remarkable degree of ignorance prevails respecting the literature and history of that portion of our island, in which such of the aboriginal race, as had survived the repeated shocks of foreign invasion, sought their last asylum from the swords of their enemies. While the national peculiarities, whether in manners or literature, of Scotland and Ireland, have been industriously explored, and, in many instances, successfully developed, Wales has been regarded with an indifference not easily to be reconciled with that spirit of enterprise, by which the literary republic of Great Britain is known to be animated. ${ }^{13}$

It was in the nineteenth century that the Welsh language began to be used for biography as an alternative to English. Conflicting allegiances are apparent in the publishing career of Robert Williams (1810-1881),

11 Including that of Sir Rhys ap Thomas, see note 8 above.

12 Foremost in Owen's pantheon of mythic nation builders was 'Hu Gadarn, or Hu the Mighty, the patriarch of the Cymry, who first established them in a civil community, taught them agriculture with other useful arts, and conducted them to the West of Europe'. William Owen, The Cambrian Biography: Or Historical Notices of Celebrated Men Amongst the Ancient Britons (London: E. Williams, 1803), $178-80$.

13 John H. Parry, The Cambrian Plutarch: Comprising Memoirs of Some of the Most Eminent Welshmen, From the Earliest Times to the Present (London: W. Simpkin and R. Marshall, 1824), [iii]-iv. 
an Anglican clergyman who first ventured into the field of biography with a slim volume in Welsh, Coviant Byr, am rai o'r dynion enwocav a aned yn Nghymru er amser y diwygiad, published by the Cymmrodorion Society in London in 1833. This was followed by an English version of the same work, ${ }^{14}$ and then by a much more ambitious collection which paid only lip-service to the Welsh language with the first two words of its title, Enwogion Cymru: A Biographical Dictionary of Eminent Welshmen From Earliest Times to the Present. ${ }^{15}$ The decisive shift towards English can be explained not only by the desire to reach an audience outside Wales, but also by the commonly held utilitarian belief that the Welsh language belonged to the past and that English was essential for the progressive education of the people of Wales.

Nevertheless, the Welsh language continued to be used for a wide range of publications, including biography. The main reason for this was the rise of Nonconformism, in particular the Methodist movement, in eighteenth-century Wales. Nonconformists put great emphasis on literacy, promulgated through Sunday schools, in order to read the Bible which had been available in Welsh since 1588 . Because the vast majority of the population were monoglot Welsh-speakers, this had the unintended consequence of creating a reading public with a voracious appetite for Welsh-language printed books and periodicals. The most distinctive literary genre of the nineteenth century was the cofiant, the biography of a minister of religion, weighty tomes celebrating the new cultural elite of Welsh society. From the root cof ('memory'), cofiant is still the normal Welsh term for a biography, with much more positive connotations than the calque bywgraffiad, implying a life worthy of memorial, indeed originally a manifestation of God's providence. These individual lives then fed into collective biographical volumes published in Welsh, ${ }^{16}$ and they constitute one reason for the predominance of ministers in modern collections.

14 Robert Williams, A Biographical Sketch of Some of the Most Eminent Individuals Which the Principality of Wales Has Produced Since the Reformation (London: H. Hughes, 1836).

15 Robert Williams, Enwogion Cymru: A Biographical Dictionary of Eminent Welshmen From Earliest Times to the Present (Llandovery: William Rees, 1852). This title is clearly modelled on that of the four-volume work by Robert Chambers, A Biographical Dictionary of Eminent Scotsmen (London: Blackie and Son, 1835).

16 For instance Josiah Thomas Jones, Geiriadur bywgraffyddol o enwogion Cymru (Aberdare: J. T. Jones a’i Fab, 1867-70); and Isaac Foulkes, Geirlyfr bywgraffyddol o enwogion Cymru (Liverpool: I. Foulkes, 1870). 
Welsh-language culture was also promoted by the Eisteddfod, a cultural festival of medieval origin which was reinvented and popularised by London Welsh societies from the late eighteenth century. Heavily influenced by romantic antiquarianism, the Eisteddfod was a site of contention between the Welsh and English languages for much of the nineteenth century, but Welsh eventually won out and the festival is today a bastion of the language. Before the advent of higher education in Wales, the Eisteddfod did much to promote scholarship by its competitions in a wide range of fields, including biography. A prize was offered in 1904 and again in 1906 for the best list of famous Welsh people between 1700 and 1900, which resulted in a flurry of publications in both languages over the following years. ${ }^{17}$

\section{Genesis of the Dictionary of Welsh Biography}

However, by the turn of the twentieth century the amateurism of the Eisteddfod was already outdated as a result of the new standard set by the British Dictionary of National Biography $(D N B)$, and the development of national institutions laid the necessary foundations for an undertaking of a similar standard in Wales. The University of Wales, established in 1893 as a federal university with colleges at Aberystwyth, Bangor, and Cardiff, provided the research base of professional historians (some of whom contributed to the $D N B$ ), whilst the National Library of Wales, founded in Aberystwyth in 1907, brought together the necessary source materials. It is interesting to note that those two institutions did set up a project which is quite comparable to the biographical one; namely, a historical dictionary of the Welsh language, modelled on the Oxford English Dictionary, which the University of Wales Board of Celtic Studies established at the National Library in $1920 .^{18}$

But the stimulus for a biographical dictionary came a generation or so later, and once again it was the London Welsh who took the lead. W. Jenkyn Thomas (1870-1959), a schoolteacher from Merionethshire, broadcast an appeal on West Regional Radio in May 1936 which shows clearly the impulse to emulate the English model in a spirit of national pride:

17 T. R. Roberts, Eminent Welshmen: A Short Biographical Dictionary of Welshmen Who Have Attained Distinction From the Earliest Times to the Present, vol. 1, 1700-1900 (Cardiff: Educational Publishing Company, 1908) is a notable predecessor to The Dictionary of Welsh Biography.

18 Published in print as Geiriadur Prifysgol Cymru (Cardiff: University of Wales Press, 1950-2002), and now available online at www.geiriadur.ac.uk/. 
I want to see published a Dictionary of Welsh Biography which will do for Wales what that magnificent English publication, unequalled even in Germany, the Dictionary of National Biography, the D.N.B as it is usually called, has done for the British Isles as a whole. ${ }^{19}$

Whilst admitting that the $D N B$ did include 'a very large number of biographies of Welshmen and Welshwomen', Thomas claimed that 'the editors did not know as much about Wales as about England, Scotland and Ireland, and they did not apply their principles of admission as adequately to Wales as they did to the other three countries' ${ }^{20} \mathrm{He}$ went on to give examples of Welsh contributions to British and world history, and concluded with an appeal for finance and organisation:

Here is a glorious opportunity for the leaders of Welsh national life to get together with a view to providing the necessary finance, organising the work, and thereby rendering an inestimable service to their nation.

What individual or society will take the initiative? ${ }^{21}$

The age of the heroic individual was past, and this enterprise clearly required the support of a society. The challenge was duly taken up by the Honourable Society of Cymmrodorion, which was still an influential force in Welsh cultural life. Planning and fundraising took place in 1937, and the project was announced by John Edward Lloyd (1861-1947), professor of history at the University College of North Wales, Bangor, in a meeting of the Cymmrodorion at the National Eisteddfod in Cardiff on 1 August 1938. As Wales's foremost academic historian, a fellow of the British Academy, author of a seminal study of early nation building (A History of Wales to the Edwardian Conquest (1911)), and contributor of over 100 entries to the $D N B$, Lloyd was the natural choice as editor of the proposed biographical dictionary. ${ }^{22} \mathrm{He}$ was to be assisted by another Bangor historian, R. T. Jenkins, and thus the University of Wales can be seen to have given academic credibility to the project.

19 The text of Thomas's broadcast was published by Brynley F. Roberts as an appendix to his article on the history of Welsh biographical writing, 'Dechreuadau'r Bywgraffiadur Cymreig', Y Traethodydd CLXVII, no. 703 (2012): 246-58.

20 Roberts, 'Dechreuadau'r Bywgraffiadur Cymreig', 253.

21 Roberts, 'Dechreuadau'r Bywgraffiadur Cymreig', 255.

22 See Huw Pryce, J. E. Lloyd and the Creation of Welsh History: Renewing a Nation's Past (Cardiff: University of Wales Press, 2011). 
The text of Lloyd's speech announcing the project was published in the Cymmrodorion Transactions for that year, ${ }^{23}$ and the view he expressed on the question of language is somewhat surprising. Faced with the choice between English and Welsh, he held that 'the argument in favour of an English work is decisive'. Whilst admitting that the Welsh language was appropriate for works dealing with Welsh literature, he argued that 'the history of the country is on a different footing'. But he grudgingly accepted the possibility of subsequent publication in Welsh: 'The fact that the work is issued in English does not preclude its issue in Welsh, for the research work will have been done'. ${ }^{24}$

Until I read the texts of Thomas's radio appeal and Lloyd's speech, I had assumed that one reason for establishing a separate Welsh biography was in order to ensure bilingual publication. However, Thomas made no mention of language at all, and for Lloyd Welsh seems to have been a secondary issue. Lloyd's attitude towards the Welsh language was typical of the Victorian Wales of his youth, in that he saw its value as limited to certain domains, primarily religion, literature, and the home, excluding the practical and public domain of history. This is borne out by his own publication practice; although he published some articles in Welshlanguage journals, all his major historical works were in English, which he clearly regarded as the language of serious scholarship.

However, Lloyd's statement does not reflect the actual publication history, since as already noted the Welsh-language volume preceded the English one by six years, and two supplementary volumes were published in Welsh in 1970 and 1997 covering the period 1941-70, before a single English volume covering the same period was published in $2001 .{ }^{25} \mathrm{I}$ am not aware of any evidence of a change in official policy on the question of language, and it may be that others did not consider the argument in favour of English to be as 'decisive' as Lloyd thought. It must also be noted that

23 J. E. Lloyd, 'A Dictionary of Welsh Biography', Transactions of the Honourable Society of Cymmrodorion (1938): 67-75.

24 Lloyd, 'Dictionary of Welsh Biography', 74-75.

25 R. T. Jenkins and E. D. Jones, eds, Y Bywgraffiadur Cymreig 1941-1950 (Llundain: Anrhydeddus Gymdeithas y Cymmrodorion, 1970); E. D. Jones and Brynley F. Roberts, eds, Y Bywgraffiadur Cymreig 1951-1970 (Llundain: Anrhydeddus Gymdeithas y Cymmrodorion, 1997); R. T. Jenkins, E. D. Jones, and Brynley F. Roberts, eds, The Dictionary of Welsh Biography 1941-1970 (London: The Honourable Society of Cymmrodorion, 2001). 
Lloyd's period as editor was relatively short; due to the outbreak of World War II work did not begin in earnest until late 1943, and Lloyd died less than four years later in 1947, to be succeeded as editor by R. T. Jenkins.

The change in attitude towards the Welsh language, if such there was, may also have been a result of the National Library's involvement in the project, since Welsh was the main working language of that institution. When J. E. Lloyd died in 1947 the national librarian, Sir William Llywelyn Davies, was appointed assistant editor to Jenkins, and several members of the library's staff undertook to write entries. Two subsequent national librarians served as editors of the $D W B$ for almost 50 years between them, Dr E. D. Jones from 1965 to 1987, and Dr Brynley Roberts from 1987 until the end of 2013, both working on a voluntary basis long after their retirement from the library. Since 2014 the project has been a partnership between the National Library and the University of Wales Centre for Advanced Welsh and Celtic Studies.

On the other hand, it may be a mistake to assume that precedence in publication necessarily meant a higher status for the Welsh language in the project. There was undoubtedly an element of pietas involved, and possibly also commercial considerations since there was a more dependable market amongst Welsh speakers at that time, but the truth is that the English volumes are more accurate than the Welsh ones simply because of the opportunity provided by later publication to correct errors and include new information.

An example of the kind of differences that can arise between Welsh and English articles is the treatment of the extramarital affairs of the politician David Lloyd George (1863-1945). In the Welsh article, written before 1955 (the date of the death of its author, the journalist E. Morgan Humphreys) and published in 1970 in the first supplementary volume, these are ignored completely, and his marriage to Frances Stevenson in 1943 after the death of his first wife is simply noted without any explanation that she had been his long-term mistress. ${ }^{26}$ The English article, published in 2001, does at least explain that Stevenson was 'his long-serving personal assistant and companion', employing a fairly transparent euphemism. ${ }^{27}$ Whether this difference was the work of the

26 Edward Morgan Humphreys, 'Lloyd George, David', in Jenkins and Jones, $Y$ Bywgraffiadur Cymreig 1941-1950, 39-40.

27 Edward Morgan Humphreys, 'Lloyd George, David', in Jenkins, Jones, and Roberts, The Dictionary of Welsh Biography 1941-1970, 176-77. 
original author or of later editors cannot now be ascertained, but in any case the reluctance to besmirch the good name of this national hero seems to have been at its most acute in the Welsh language. The need for a new article giving a full picture of the public and private life of Lloyd George is obvious.

Publication of parallel print volumes in Welsh and English presented considerable financial and logistical challenges, and due credit must be given to the role of the Cymmrodorion Society in raising the necessary funds and managing the project for over 60 years. Despite time lags in publication and minor discrepancies between the versions, the crucial thing was that biographies of people who died up to 1970 were available in both languages by the time that digital technology made it possible to combine the two in a single online resource. Welsh Biography Online/ $Y$ Bywgraffiadur Ar-lein was launched in 2007 on the National Library of Wales website, ${ }^{28}$ containing digitised and searchable versions of all the articles from the five print volumes, with the facility to switch directly from one language to the other. Since then, all new articles have been published online only, and in Welsh and English simultaneously, in accordance with the strict bilingual policy maintained by the National Library for all its online resources.

\section{Bilingualism in Wales}

Full bilingualism of this kind has become normalised since the establishment of the National Assembly for Wales following the referendum on devolution in 1999. All public bodies are now required to operate bilingually, monitored by the Office of the Welsh Language Commissioner. In terms of language policy, the general consensus since devolution has been in favour of a bilingual country in which speakers can use the language of their choice, with a substantial proportion capable of working in both Welsh and English. In its 'National Action Plan for a Bilingual Wales' of 2003 the Assembly Government set out its aspiration for:

28 National Library of Wales, yba.llgc.org.uk/en. The title was changed in 2014 to Dictionary of Welsh Biography/Y Bywgraffiadur Cymreig, since there is no longer any intention to publish further print versions. 
a truly bilingual Wales, by which we mean a country where people can choose to live their lives through the medium of either or both Welsh or English and where the presence of the two languages is a source of pride and strength to us all. ${ }^{29}$

This aspiration has to be set against a background of continuous decline in the percentage of Welsh speakers over the last 200 years. At the beginning of the nineteenth century it is estimated that about 72 per cent of the population of Wales were Welsh speakers, many of them monoglot, and although the proportion decreased gradually during the century there was an increase in absolute numbers to around a million due to population growth, which explains the existence of a thriving Welsh-medium print culture in nineteenth-century Wales. ${ }^{30}$ By the census of 1891 , which was the first to require information on language in Wales, the proportion of Welsh speakers was 54.5 per cent, and by 1931 this had decreased to 36.8 per cent, of which just under a third were monoglot speakers. ${ }^{31}$ The decline continued over the following decades, but numbers stabilised towards the end of the twentieth century at just over half a million, or 20 per cent of the population, mainly as a result of activist campaigns in support of the language, particularly through Welsh-medium education, which led to an increase in the number of young people able to speak Welsh. The Welsh Government recently issued a strategy paper setting out its vision for a million Welsh speakers by 2050, an extremely ambitious target that could only be realised by further growth in Welsh-medium education at all levels. ${ }^{32}$

As a fully bilingual source of information about the history of Wales, the $D W B$ is a vital component in any strategy using education to promote the Welsh language, not only in practical terms but also for its symbolic value as one of a small but growing number of online resources which demonstrate to young people that Welsh has not been left behind by the digital revolution. Considerable effort is also being put into the

29 'Iaith Pawb [Everyone's Language]: A National Action Plan for a Bilingual Wales', March 2003, accessed 14 November 2016, gov.wales/topics/welshlanguage/publications/iaithpawb/?lang=en.

30 Dot Jones, Statistical Evidence Relating to the Welsh Language 1801-1911 (Cardiff: University of Wales Press, 1998), 211-25. For a useful general survey, see Janet Davies, The Welsh Language: A History (Cardiff: University of Wales Press, 2014).

31 Geraint H. Jenkins and Mari A. Williams, eds, Let's Do Our Best for the Ancient Tongue: The Welsh Language in the Twentieth Century (Cardiff: University of Wales Press, 2000), 34.

32 'Cymraeg 2050: Welsh Language Strategy', accessed 27 March 2019, gweddill.gov.wales/ topics/welshlanguage/welsh-language-strategy-and-policies/cymraeg-2050-welsh-language-strategy/? lang=en. 
development of a Welsh-language version of Wikipedia, which now has over 80,000 articles, ${ }^{33}$ and collaboration with the $D W B$ has recently begun to contribute data and authoritative source references.

The DWB itself was never intended for use by schoolchildren, and the fact that most of its articles have not been revised for over 50 years makes its language and style even less accessible. Separate versions of selected articles for use in schools would be desirable, and this is under consideration. As it stands, the $D W B$ is of value for Welsh-medium education primarily at university level. Demand for courses through the medium of Welsh in the universities of Wales was a natural consequence of the success of Welsh-medium secondary schools, and provision has been supported since 2011 by a national Welsh college, Y Coleg Cymraeg Cenedlaethol. Source material in Welsh is valuable not just to those studying Welsh history and literature, but also to students across a wide range of science and humanities subjects seeking information on pioneers of their fields from Wales. And staff appointed to strengthen Welsh-medium provision in the universities are now in a position to contribute articles in their specialist areas.

Although Welsh is spoken by only one in five of the population, the existence of the language is an important marker of national distinctiveness for a much greater proportion of the people of Wales. And those who are active in Welsh-language culture tend to gain the prominence which justifies inclusion in a national biographical dictionary, as writers, preachers, politicians, musicians, and even rugby players. A good example is Richard (Dic) Jones (1934-2009), a farmer and bardd gwlad (country or community poet), one of the finest exponents of the modern bardic craft, who won the Chair at the National Eisteddfod in 1966. ${ }^{34}$ Another, particularly relevant to Welsh in education, is T. Llewelyn Jones (19152009), best known as a children's writer who did a great deal to encourage Welsh-speaking children to delight in reading their own language. ${ }^{35}$ Given his fame in Wales, it is interesting to note that T. Llew, as he is always known, has not been included in the new Oxford Dictionary of National

\footnotetext{
33 'Wicipedia: Y Gwyddoniadur Rhydd', cy.wikipedia.org/wiki/Hafan.

34 Idris Reynolds, 'Jones, Richard Lewis ('Dic')', Dictionary of Welsh Biography/Y Bywgraffiadur Cymreig, accessed 8 January 2019, bywgraffiadur.cymru/article/c10-JONE-LEW-1934.

35 Idris Reynolds, 'Jones, Thomas Llewelyn', Dictionary of Welsh Biography/Y Bywgraffiadur Cymreig, accessed 8 January 2019, bywgraffiadur.cymru/article/c8-JONE-LLE-1915.
} 
Biography, which just goes to show how important the $D W B$ is in ensuring a record of those whose contribution did not extend beyond the Welsh context.

It is perfectly natural that Welsh should be the primary language for recording lives such as these. But in a bilingual dictionary Welsh must encompass all aspects of national life, including spheres in which it has traditionally played little role, such as business and science. This has been facilitated by the development of terminology for Welsh-medium education, which has occurred largely since the publication of the first volumes of the $D W B$. A straightforward example is to be found in the article on the Tudor mathematician Robert Recorde (c. 1512-1558) from Tenby, inventor of the equals sign. The original English article states that 'to him is due the invention of the sign of equality $(=)$ ', but the Welsh gives no term for the mathematical concept of equality, referring simply to ' $y$ simbol ='. When a new article was published in 2016 the Welsh version was able to use hafaledd, which is now the standard term for that concept. ${ }^{36}$ There was in any case a tendency in the early volumes to gloss over technical details of subjects' achievements, particularly those of women. A case in point is Frances Hoggan (1843-1927), the first Welsh woman to qualify as a doctor. The original article on her is very brief and gives no details about her work in either language. A fuller article has just been published, to coincide with the establishment by the Learned Society of Wales of the Frances Hoggan Medal to recognise Welsh women's contribution to science, and the Welsh-language version of that article copes easily enough with terms such as 'progressive muscular atrophy'. ${ }^{37}$

Not the least of the $D W B$ 's contributions to widening the vocabulary of contemporary Welsh is its one-word term for a biographical dictionary, bywgraffiadur, coined in 1952 by one of its committee members, the scholar and author T. H. Parry-Williams, just in time to be used in its

36 James Frederick Rees, 'Recorde, Robert', in Lloyd and Jenkins, $Y$ Bywgraffiadur Cymreig hyd 1940, 822; Lloyd and Jenkins, The Dictionary of Welsh Biography Down to 1940, 773; Gordon Roberts, 'Recorde, Robert', Dictionary of Welsh Biography/Y Bywgraffiadur Cymreig, accessed 8 January 2019, bywgraffiadur.cymru/article/c11-RECO-ROB-1558.

37 R. T. Jenkins, 'Hoggan, Frances Elizabeth', in Lloyd and Jenkins, Y Bywgraffiadur Cymreig hyd 1940, 338; Lloyd and Jenkins, The Dictionary of Welsh Biography Down to 1940, 359; Beth Jenkins, 'Hoggan (née Morgan), Frances Elizabeth', Dictionary of Welsh Biography/Y Bywgraffiadur Cymreig, accessed 8 January 2019, bywgraffiadur.cymru/article/c11-HOGG-ELI-1843. 
Welsh title. Formed by adding the suffix of the Welsh term for dictionary, geiriadur, to the root of the calque bywgraffiad ('biography'), this is an extremely handy term which has no equivalent in English.

\section{Other Bilingual Biographical Dictionaries}

The $D W B$ is by no means the only national biographical dictionary to be published in more than one language. Two others within the Englishspeaking world are the Dictionary of Canadian Biography/Dictionnaire biographique du Canada in English and French, and the Dictionary of New Zealand Biography with its parallel series in the Māori language, Nga Tāngata Taumata Rau. In both cases the two languages were originally published in separate print editions, and have recently been integrated into online resources that demonstrate the potential of digital technology to facilitate bilingual dissemination. Both also offer interesting contrasts to the $D W B$, which perhaps reflect the relationship between the language communities in the respective countries. Whereas the $D W B$ has one general editor dealing with contributions submitted in either English or Welsh (or both), Canada's dictionary is produced by separate teams at two collaborating institutions: the University of Toronto being responsible for the English version and l'Université Laval for the French version. ${ }^{38}$ The New Zealand dictionary provides a selective form of bilingualism along ethnic lines, the user interface being available in both languages but, apparently, only Māori people having entries in both Māori and English. ${ }^{39}$

\section{Translation Issues}

When a minority language coexists in a bilingual situation with a majority language there is a tendency for the former to adjust its vocabulary towards a one-to-one correspondence with that of the latter. That tendency is certainly evident in the $D W B$ articles, particularly those published since the launch of the website, and makes it possible to achieve a good degree of equivalence between the two languages. Nevertheless, there are still plenty of resonances unique to Welsh which are resistant to direct translation.

38 'About Us', Dictionary of Canadian Biography/Dictionnaire biographique du Canada, accessed 14 November 2016, www.biographi.ca/en/about_us.php.

39 Te Ara-The Encyclopedia of New Zealand, accessed 14 November 2016, teara.govt.nz/en/ biographies. 
These can be seen in some key words relating to the sense of place and belonging, which serve to illustrate how language can encapsulate 'ways of thinking. ${ }^{40}$

A highly positive term for region or neighbourhood, with strong connotations of organic community, is bro. A measure of the importance of this word for Welsh identity is the fact that it is the root of the ethnic identifier Cymro ('Welshman', literally 'fellow-countryman'), the plural of which gave the name of the country itself, Cymru. An example of one of many significant uses of the word in the DWB occurs in the article on William John Gruffydd (1881-1954) by Sir Thomas Parry, one of the finest Welsh prose writers of the twentieth century. Speaking of Gruffydd's memoirs, Parry stated that they reflected the men and women of his native parish and the Welsh people at a crucial time in their history', a translation which conveys the meaning but not the positive resonance of the Welsh 'o'r fro lle magwyd ef, ac o genedl y Cymry mewn cyfnod pwysig yn ei hanes'. There is a similar flattening in the rendering of cenedl (originally 'kin' and now 'nation') as 'people', and the progression within that Welsh sentence from bro (in its mutated form fro) to cenedl has political significance in itself which is entirely lost in the English. ${ }^{41}$

Losses in translation are not confined to words of native origin. A phrase which has taken on cultural resonance as a result of its use by the modern author D. J. Williams (1885-1970) of his own neighbourhood of Rhydcymerau in Carmarthenshire is milltir sgwâr (literally 'square mile', the second word being an English borrowing). This is used in the article on Richard (Dic) Jones referred to above, who is described in English as 'a countryman whose feet were firmly rooted in the land to which he belonged', and in Welsh with a stronger sense of solid foundation as 'gwladwr ầi draed yn gadarn ar ddaear ei filltir sgwâr'. ${ }^{42}$

The Welsh used in the $D W B$ is of necessity a combination of traditional and contemporary, with the new terminology of recent decades alongside a lexical core with connotations accrued over centuries. As in

40 James Walter claimed in 'Seven Questions about National Biography' that 'arguably "the national" is most truly alive in ways of speaking, ways of thinking', in National Biographies and National Identity: A Critical Approach to Theory and Editorial Practice, eds Iain McCalman with Jodi Parvey and Misty Cook (Humanities Research Centre, The Australian National University: Canberra, 1996), 19-34 (at 21).

41 Thomas Parry, 'Gruffydd, William John', in Jones and Roberts, Y Bywgraffiadur Cymreig 19511970, 67; Jenkins, Jones and Roberts, The Dictionary of Welsh Biography 1941-1970, 86.

42 Reynolds, 'Jones, Richard Lewis ('Dic')'. 
any biographical dictionary, many of the articles now being added deal with people brought up before World War II, when monoglot Welsh communities in rural Wales preserved forms of speech extending back across generations. As the poet D. Gwenallt Jones (1899-1968) said of his family connections in the iconic Rhydcymerau, with reference to the great Methodist hymnwriter of the eighteenth century: 'I remember my grandmother ... the Welsh on her lips the Welsh of Pantycelyn'. ${ }^{43}$

Whilst in one sense the Welsh language constitutes an element of continuity which makes it essential to any true representation of the history of the Welsh people, this chapter has also shown that its significance is more than just backward-facing. Within the 80 years of the $D W B$ 's existence the condition of the Welsh language has changed enormouslyfor the worse in terms of number of speakers but very much for the better in terms of usage and official status. The new language policy resulting from political devolution coincided with the development of digital technology, making it possible to bring together the contents of the print volumes to form an integrated resource which will be of enormous practical and symbolic value as Wales seeks to fulfil the aspiration to become a truly bilingual country.

43 'Rwy'n cofio am fy mam-gu ... àr Gymraeg ar ei gwefusau oedrannus yn Gymraeg Pantycelyn'. D. Gwenallt Jones, 'Rhydcymerau' in Eples (Gwasg Gomer: Llandysul, 1951). The translation quoted is by Joseph Clancy, Twentieth Century Welsh Poems (Gomer Press: Llandysul, 1982), 100. On the eighteenth-century hymnwriter Williams Pantycelyn, see Gomer Morgan Roberts, 'Williams, William', Dictionary of Welsh Biography/Y Bywgraffiadur Cymreig, accessed 8 January 2019, biography. wales/article/s-WILL-WIL-1717. 
This text is taken from 'True Biographies of Nations?': The Cultural Journeys of Dictionaries of National Biography, edited by Karen Fox, published 2019 by ANU Press, The Australian National University, Canberra, Australia.

doi.org/10.22459/TBN.2019.09 